\author{
Mr. C. M. Rice \\ Nuclear Rocket Operations \\ Aerojet-General Corporation \\ P. 0 . Box 15847 \\ Sacramento, California 95813 \\ Attention: A. Schaff, Jr. \\ Subject: E/STS-2\&3 Activation Guide, Preliminary Issue \\ Dear Mr. Rice:
}

Attached is the Preliminary Issue of the E/STS-2\&3 Activation Guide. If further information concerning this document is required, please contact Mr. R. G. Staker or Mr. A. W. Magnusson.

\title{
Sincerely yours,
}
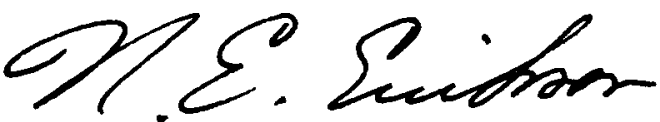

RS N. E. Erickson, Manager

NERVA Test Operations

$A W M: N E E: j j$

Attachment: E/STS-2\&3 Activation Guide, Preliminary Issue

This report NoTICE

sponsored was prepared as an account of work the United the United States Government Neither Research and States nor the United States Energy theur er theu employees, nor any of their contractors, subcontractors, or their employees, makes any warranty, express or impled, or assumes any legal Lability or responsibulity for the accuracy, completeness or usefulness of any information, apparatus, product or process disclosed, or represents that its use would not infringe privately owned rights. 


\section{DISCLAIMER}

This report was prepared as an account of work sponsored by an agency of the United States Government. Neither the United States Government nor any agency Thereof, nor any of their employees, makes any warranty, express or implied, or assumes any legal liability or responsibility for the accuracy, completeness, or usefulness of any information, apparatus, product, or process disclosed, or represents that its use would not infringe privately owned rights. Reference herein to any specific commercial product, process, or service by trade name, trademark, manufacturer, or otherwise does not necessarily constitute or imply its endorsement, recommendation, or favoring by the United States Government or any agency thereof. The views and opinions of authors expressed herein do not necessarily state or reflect those of the United States Government or any agency thereof. 


\section{DISCLAIMER}

Portions of this document may be illegible in electronic image products. Images are produced from the best available original document. 


\section{MASTER}

DISIRIBUIION OF IHIS DOCUMENI UNLIMIIED

$$
x . \ln 249
$$




\section{MASTER}

NTO-I -0232

\section{PRELIMINARY}

\section{E/STS $2 \& 3$ ACTIVATION GUIDE}

R G STAKER

A W MAGNUSSON

A J POWELL

D D VANDERMEER

D L LIMBACHER 


\section{Abstract}

This document describes the various activities shown on the E/STS-2\&3 activation guide network, Figure 1, and represents the initial NTO effort in support of the major E/STS-2\&3 activation activities. It is NTO's intent to upgrade this document from time to time as designs and guidelines change or become firm.

Logic for the conduct of the various activities has been based on ETS-1 activation experience and backup references have been included for similar ETS-1 activities where applicable. The information contained herein is based on available information and may not reflect the most current E/STS-2\&3 concepts. One of the purposes of this document is to identify the special test equipment (STE) requirements for facility activation. These articles, in addition to major requirements, are to be found under the activity heading "Requirements". Preliminary sketches of major STE have also been included to supplement the written description and generally acquaint the reader with these concepts. 


\section{ACTIVITY}

B 0 D - ALL ACTIVITIES

\section{$\underline{\text { Summary }}$}

Buy-Off-Date (BOD) is the formal acceptance by the operating contractor of the systems from the construction contractor. Upon BOD it is expected that the system will be ready, without further construction or maintenance effort, for the first identified activity. The effectiveness of BOD is dependent primarily upon the adequacy of the construction specifications and the construction followup. It is assumed that the following action will be taken to minimize the problems encountered after $B O D$, such as rebuilding and/or recleaning systems, and hence minimize the costs (monetary and time) of correcting system deficiencies :

a) Specifications will be prepared in such a manner that the appropriate construction standards are a requirement on the contractor. Included in this category are rigid Quality Control and workmanship standards such as :

1. Detailed welding standards, non-destructive testing requirements, and acceptance standards for the nondestructive test results.

2. Pipe fit-up requirements, especially at mating flanges or joints to assure proper system integrity. 
3. Pipe mounting requirements to assure adequate tie-down

4. Cleanliness requirements to assure adequate precautions are taken during construction, and final verification of cleanliness upon completion of construction.

The specifications, should be reviewed by the operating contractor to ensure that operational considerations are factored into the design.

b) Construction followup of the contractors effort will be in sufficient detail to insure that the requirements of the specifications are satisfied. A thorough quality inspection program will be instituted to assure strict compliance with the specifications. Operating contractor personnel will be intimately involved in the followup effort to ensure that when corrective acticn is needed, it is taken by the construction contractor and that operating personnel are fully aware of construction history.

c) The operating contractor will generate acceptance test procedures to provide maximum assurance of complete checkout and to minimize any duplication of checkout effort before and after BOD. The results of acceptance testing will be thoroughly documented and reviewed by operations personnel to insure that acceptance testing requirements are satisfied.

d) Premature BOD will not occur in order to meet construction schedules at the later expense of activation schedule.

e) Facility performance (fluid systems) specifications to which the facility is designed will be compatible with initial test specifications. 
"Initial Fill and Simulated Duct Flow Tests"

\section{Summary}

This test will be conducted to gain system information on and operating characteristics of the water supply and return line installation. Specific objectives are:

1. Valve dynamic performance under load

2. Cavitation suppression techniques

3. Effect on shield and steam generator water supply pressure at duct full flow conditions

II. Requirements

1. Duct Simulator (series of muti-holed orifice plates)

2. SGS and Shield Flow Simulator (fixed orifices)

3. Special Purpose Diagnostic Instrumentation (water hammer effects)

4. Controls Trailer

III. References

1. IF-I Test Report

- NTO-S-005

2. IF-2 Test Report

- NTO-R-009

3. IF-3 Test Report

- NTO-R-004I

4. IF-4 Test Report

- NTO-R-0098

5. Pulsation Controls Report

- $\quad$ R-177 


\section{ACTIVITY}

\section{"DUCT WATER FLOW TESTS"}

\section{SUMMARY}

This activity will demonstrate the Duct operation performance, determine the variation from design for the purpose of final adilustment water flow rate through the several paths. A secondary objective is to optimize fill and drain flow control procedures plus entire system checkout.

II. REQUIREMENTK
A. Permanert Instrumentation Instalied
B. Temporarv Diagnostis Measurement Devices
$\therefore$ Permanent, Control System Installad

\section{SACKTP RELEFHTCES}

4. Test Speijfication ............ RN-S-0127, Phase II

B. Test Des ription ............. NTO-I-0137

c. Control zoam Procedure ........... NTO-M-13160

D. Final Report ................ NTO-R-0106 


\section{SHIMDS: "WATHR FLON TESTS"}

\section{SUMMARY}

This activity covers the checkout of the shield rater system. The shields will be fllled with water (no boron) using the mixing stations and circulating water pumps. The pumps will be used to transfer water from shield to shield and also to circulate the water in the lower and intermediate shields, using simulated signals to the control valves to verlfy proper heat exchanger operation. Transient conditions resulting from simulated fallure of a circulating water pump will be determined, using all possible pump cambinations.

In a separate checkout, the satisfactory operation of the chemical mixing stations will be verified, using prescribed chemicals. The effluent water w1ll be analyzed to verify proper chemical concentrations.

II. REQUIREMIENTS

A. Shield and Shield Water Systems Completed

B. Facility Water Supply

C. Permanent or Temporary Controls and Instrumentation

D. Pump Power 
II. (Continued)

E. Limited Supply of Orthoboric Acid and Borax

F. Facilities for Chemical Analysis

G. Storage or Disposal of Iimited Quantities of Borated Water

III. BACKUP REFERENCES 


\section{ACTIVITY}

\section{SHIELDS: "MECHANICAL SEAL AND LEAK TEST"}

\section{SUMMARY}

This activity covers the verification of the shield positioning equipment operation, the integrity of the mechanical seals, and a leak check of the Engine Test Compartment (ETC). The shields will be positioned, seal make-up completed, and the Duct will be sealed off with a test plug. The ETC will be evacuated using temporary vacuum pumps and all seals will be checked for leakage. The shield seals will be broken and the shield will be repositioned to simulate preparation for engine removal.

II. REQUIREMTENTS
A. Shield Construction Completed
B. Test Plug
C. Temporary High Capacity Vacuum Pumps
D. Shield Water Supply
E. Shield Gas Purge Supply
F. Simulated Lower Tank Structure

III. BACKUP REFEREMTCES

A. Procedure for ETC Nechanical, Seal and Leak Test (NTO-I-0165) 


\section{ACTIVITY}

\section{SHIEIDS: "GN2 PURGE TESTS"}

\section{SUMMARY}

This activity covers the nitrogen purge tests of the Engine Test Compartment (ETC) to determine the optimum method of $\mathrm{Gl}_{2}$ purge for inerting the ETC and Duct. The operation of the $\mathrm{H}_{2} / \mathrm{O}_{2}$ analyzers will be checked and the location of the probes will be optimized. The $\mathrm{Gr}_{2}$ will be released into the ETC, discharged through the exhaust duct and released to atmosphere.

\section{REQUIREMIHTTS}
A. Shield Construction Completed
B. Simulated Iower Tank Structure
C. Temporary $\mathrm{O}_{2}$ Analyzer System
D. $\mathrm{GN}_{2}$ Parge Supply

III. BACKUP REFEREMTCBS
A. Test Description CEP-I - ETC Purge Tests (NTO-I-0144) 


\author{
Activity \\ "Component Leak Check \\ and \\ Electromechanical Checkout"
}

I. Summary

This activity is to insure the integrity of the steam generator components. These preliminary component tests are required for:

1. Pressure Switch calibrations

2. Check Valve functional tests

3. Verification of orifice size and locations

4. Operational verification of proper sequencing

5. Safety System verification

II. Reguirements

1. Local control of SGS Control System Including cold checkout device (trailer)

III. Reference

1. Test Report, SGS EP-I, NTO-R-0023
a. Page 3
b. Appendix III Change Requests 
"Steam Generator Water Flow Tests"

I. Summary

This activity covers the Steam Generator Water Flow Tests designed to demonstrate the operational performance of the coolant and injection water flow systems. This test series will accomplish the following objectives:

1. System impedance verification at various flow rates to determine minimum head reguirements.

2. Performance evaluation of injection flow control system

3. Evaluation of dynamic water flow forces (water hammer)

II. Requirements

1. Steam line simulator orificed to simulate duct injection impedance

2. Temporary diagnostic instrumentation

III. References

1. Test Report, SGS Development Program, EP-IV - NTO-R-0061, Page 7 


\section{Activity}

"Steam Generator Idle Tests"

I. Summary

This activity covers the initial firing of the individual steam generator units to accomplish the following objectives:

1. Determine the operating characteristics of the individual steam generator units at idle.

2. Investigate interaction effects of one module on another during multiple module operation.

3. Complete system checkout of propellant supply system with real hardware.

4. Initial checkout of controls and safety circuits under operating conditions.

II. Requirements

1. Over board steam line with orifice to simulate injector back pressure.

2. Block valve in steam line to facilitate system leak and pressure tests.

3. Special purpose diagnostic instrumentation

III. References

1. IMP-I Test Specification

RN-S-0203

2. Test Description (EP-I)

NTO-I-0027

3. Test Report EPP-I

NTO-R-0033 


\section{"STEAM GENERATOR COMPLEME SYSTEM CHECKOUT"}

\section{SUMMARY}

A. Individual checkout of each unit at full steam to determine:

1. Proper Unit Operation

2. Determine Proper Mixture Ratio

3. Performance Evaluation

B. Multiple module operation to determine:

1. Interaction Effects During Start-Up and Shutdown

2. Optimum Start-Up and Shutdown Procedure

3. Switching Tests

4. Reliability Tests

5. Duration Tests

6. Off-Design Tests

C. Evaluation of facility stean line to verify design:

1. Starting Shocks

2. High Temperature Warpage

3. Hanger Support and Snubber Systems

II. REQUIREMIMNTS

A. Overboard Steam Ifne with Switch-Over Valve to Facility Steam Ine 
II. (ContInued)

B. Fixed Orifice to Simulate Injection Back Pressure

C. Block Valve to Facilitate Pressure Tests

\section{BACKUP REFFERBMTCES}

A. Test Report - Steam Generator Development Test Program, EP-II (NTO-R-0046) 


\section{ACIIVIIY}

"MITS GI, DEMOASTRATIOA TESTS"

\section{SUMARY}

The Design Demonstration Test Program provides for cold flor testing of the NES at both NRRVA design and off-design conditions. These tests will be used to demonstrate the performance of IES prior to its use in supporting the testing of a nuclear engine. Testing at two levels of primary chamber pressure provides assurance that the duct will perform safely over the entire operating range. Testing at off-design conditions verifles that the duct performance is not marginal. The tests will be conducted at IRDS using E/STS-2 Facility (I\&C, process water, gas supply system, steam generator, test stand, and permanent engine compartment).

\section{REQUIREALETLS}

A. NGS Test Device (See Attached Sketch)

B. Sufficient Storage of $\mathrm{Gr}_{2}$ to Accomodate Flow Demand Profiles

C. Separate $\mathrm{CH}_{2}$ Supply for Turbine Bxhaust Flow

\section{BACKUP REFTREMCAS}
A. WES Design Demonstration Test Program (RI-S-0137A)
B. IVS Test Specification No. 201
C. NES Phase I Final Test Report (NTO-R-
(In Publication) 


\section{ACTIVITY}

"NES GH 2 DEMONSTRATION TESTS"

\section{Summery}

The NES Test Program will be designed to obtain the most information possible from the two test series $\left(\mathrm{GN}_{2}, \mathrm{GH}_{2}\right)$.

Test Number I ( $\left.\mathrm{GN}_{2}\right)$ investigates, above the duct "pull-in"point, the effects of excess seal leakage and excess turbine exhaust on NES and ETC performance. Also demonstrated is the ability of the SGS to function as an aerodynamic "check valve" during a simulated engine malfunction shutdown.

Test Number II investigetes, above the duct "pull-in" point, the effects of design turbine exhaust and $\mathrm{GH}_{2}$ primary flow on the NES performance and exhaust plume radiation on the NES and Test 8 tand.

II. Requirements

1. NES Test Device (See attached sketch)

2. Sufficient storage of $\mathrm{GH}_{2}$ to accommodate flow demand profiles

3. Separate $\mathrm{GH}_{2}$ supply for turbine exhaust flow

III. References

1. NES Design Demonstration Test Program - RN-S-0137A

2. NES Test Specification No. 202 
ALCOHOL TAMK V-AL-20: "GN/2 PRESSURE TEST AND PRESSURIZATIOA AID VEMTI TESTS"

\section{SUMMARY}

This activity covers the initial water fill, GN pressure test, and subsequent pressurization and vent tests on the alcohol storage vessel. The tank will be filled with water to the maximum operating level. The tank will be gradually pressurized in steps to $125 \%$ of operating pressure, using $\mathrm{GN}_{2}$ and then reduced to the leak test pressure. Any leaks will be identified and corrected. Following successful leak testing, the pressurization/venting characteristics of the tank will be established. The tank will be dried and left with an inert atmosphere upon completion of this activity.

II. REQUIREMIENTSS
A. Temporary Water Supply to Tank
B. Gir Supply Available to Tank
C. Pressurization and Vent System Operable
D. Temporary or Local Controls
E. Tank Drying Capability

III. BACXUP REHEREICES 


\section{ACIIVIIY}

\section{"FIRE PROTECTION SYSTEM, DELUGE ACTIVATION AND CHECKOUT"}

\section{SUMMARY}

This activity includes the initial introduction of water through the various test stand and facility deluge systems; with flow rates, static head pressures, and *HAD autcmatic trip pressures and temperature rates of rise recorded.

The supply vessel(s) (utility and process water tanks) will be filled, the system valve allgment normal (except for RSV's at deluge valves - shut), the system leak checked (at all flanges, packing glands, joints, etc.), the HAD system response recorded (temperatures, rates of rise) and flow rates per individual deluge system recorded.

\section{REQUIREALITIS}
A. Electrical Power
B. Demineralized Water System Completed
c. Temporary Flow Meters
D. Temporary Heat Source for HAD Checkout (Temperature Recorded)

* Heat Actuated Detector 
III. BACXUP REFERENCES
A. Safety Analysis Report
B. Safety System Control Procedure (ITO-I-0077-5)
C. Fire Protection System Setup Procedure (NTO-I-0154-1)
D. Console Setup Checklist (NTO-I-0143) 


\section{ACTIVITY}

\section{ALCOHOL TANK V-AL-2O : "WATER FLOW TESTS"}

I Summary

This activity covers the water flow tests to checkout pumps and piping systems prior to filling the tank with combustible alcohol.

Each pump (three turbine main pumps and one electric auxiliary pump) will be operated at full load conditions. The water will be pumped using the normal alcohol piping and valves to a point as close to the steam generators as is practical. A steam generator simulator will be used to provide realistic flow conditions. Upon completion of this activity the tank and piping will be dried and an inert atmosphere will be left within the system.

II Requirements

A. Temporary water supply to tank

B. $\mathrm{GN}_{2}$ supply available to tank

C. Pressurization and vent systems operable

D. Main and auxiliary pumps operable.

E. Alcohol system completed to vicinity of SG's.

F. Steam Generator simulator installed

G. Electric and steam power available for pumps

H. Alcohol system controls operable.

\section{Backup References}

None 


\section{ACIIVITY}

AICOHOL TANK V-AL-20: "AICOHOL FIIL AND FLON VERIFICATION TESTS"

\section{SUDAYARY}

This activity covers the initial alcohol fill and flow tests on the alcohol system. The tank will be filled with alcohol and all tank instrumentation will be checked. Each pump will be operated at full load conditions. All three main pumps will be operated at normal load and system transients caused by simulated single pump failure will be determined. The alcohol will be pumped using the normal alcohol piping and valves to a point as close to the steam generators as is practical. A steam generator simulator will be used to provide realistic flor conditions and alcohol disposal facilities. Upon completion of this activity, the system will be left in the normal lay-up conditions.

II. REQUIREMTENTS
A. Alcohol Supply
B. System Construction Completed, Including Pressurization Supply, Instmmentation and Controls.
C. Steam Generator Simulator (Including Alcohol Disposal Facilities) Installed.
D. Steam and Electric Porrer

III. BACKUP REFERWTCES 


\section{ACPIVIIY}

\section{"LOX TAIIK V-LO-19: GN, PRESSURE TESTS"}

\section{SUMMARY}

This activity covers the Gir pressure test on the liquid oxygen storage vessel. The vacuum jackets associated with these systems will be pumped down to operating pressure and the jackets and pumping system will be checked for operational characteristics and integrity. The tank will be gradually pressurized in steps to $125 \%$ of operating pressure using $\mathrm{GN}_{2}$ and then reduced to the leak test pressure. Any leaks will be identified and corrected. After successful leak testing, the tank will be vented and left wth an inert atmosphere.

II. REQUIREAIANTS

A. GN/2 Supply Available to Tank

III. BACKUP REFERERTCES

None 


\section{ACTIVITY \\ LOX TANK V-LO-19 : "LN2 CRYOSHOCK AND LEAK TEST"}

\section{Summary}

This activity covers the initial cryoshock $\left(\mathrm{IN}_{2}\right)$ of the LOX storage vessel and cold leak test of the vessel and associated systems.

The storage vessel will be chilled and filled to approximately $10 \%$ following pulldown of the vacuum annulus. The self-pressurization system will be checked out using $L_{2}$. All mechanical fittings in the dewar, fill and pressurization systems will be torque checked and the systems drained. While the dewar and associated systems are cold, a $\mathrm{GN}_{2} / \mathrm{GHe}$ mixture aill be introduced and the systems will be leak tested. The system will then be vented.

\section{Requirements}

1. Electrical power

2. Vacuum pumps

3. $\mathrm{LN}_{2}$ source

4. $\mathrm{GN}_{2}$ source

5. He source

6. He leak detectors

7. Temporary I\&C equipment

III Backup References

None 


\title{
ACTIVITY
}

\author{
"LOX TANK V-LO-19: LN, FLOW TESTS TO SGS INTERFACE"
}

I

$\underline{\text { Summary }}$

This activity covers the $\mathrm{LN}_{2}$ flow tests to checkout pumps and piping systems prior to filling the tank with liquid oxygen.

The tank will be filled with $\mathrm{LN}_{2}$ and pressurized to normal operating pressures using the self pressurization system.

Each pump (three turbine main pumps and one electric auxiliary pump) will be operated at full load conditions. The $\mathrm{LN}_{2}$ will be pumped using the normal $\mathrm{LO}_{2}$ piping and valves to a point as close to the steam generators as is practical. A steam generator simulator will be used to provide realistic flow conditions.

Upon completion of this activity, the tank and piping will be drained and an inert atmosphere will be left within the system.

\section{Requirements}

1. $\mathrm{IN}_{2}$ supply to tank.

2. Pressurization and vent systems operable.

3. Main and auxiliary pumps operable.

4. $\mathrm{IO}_{2}$ system completed to vicinity of $\mathrm{SG}^{\prime} \mathrm{s}$.

5. Steam generator simulator installed.

6. Electric and steam power available for pumps.

7. $\mathrm{LO}_{2}$ controls operable.

\section{Backup References}




\section{SUMMARY}

This activity covers the initial LOX fill and flow verification tests on the LOX system. The tank will be filled with IOX and all tank instrumentation will be checked. Each purmp will be operated at full load conditions. All three main pumps will be operated at normal load and system transients caused by simulated single pump failure $w 11$ be determined. The IoX will be pumped using the normal lox fiping and valves to a point as close to the steam generators as is practical. A steam generator wili be used to provide realistic flow conditions. Upon sompletion of this activity, the system will be left in normal lay-up conditions.

II. REQUIREMANTS
A. LOX Supply
B. System Construction Completed Including Instrumentation and Controls
C. Steam Generator Simulator Installed
D. Steam and Electric Power

III. BACKUP REFERENCES 


\section{ACTIVITY}

\section{"INITIAL SITE CHECKOUT OF NGM"}

\section{SURMARY}

This activity concerns itself with the initial site checkout of the NGM prior to installation in the E/STS-2 Test Stand. These activities cover the following:
A. Inspection
B. Instrmentation Installation and Checkout (Megger Instrumenta- tion and Power Bus)
C. Functional Camponent Checkout (Valves, pressure switches, etc.)

II. REQUIREMENTS
A. Inspection Building
B. Portable Electronic Checkout Devices

III. BACKUP REFERENCES

A. MAD Procedures P-1 through P-9 


\section{ACTIVITY}

\section{"TGTM PRESSURE TESTS"}

\section{SUMMARY}

This activity covers the initial pressurization tests of the NGMM using the facility pressurization control system. It is anticipated that the initial pressurization fluid will be Gir with $10 \%$ helium. The objectives of this test are:
A. Checkout NGTM Pressurization and Vent Systems
B. Leak Check of Umbilical Connections
C. Leak Check of PSOV and/or the Engine/MPT Interface

II. REQUIREAENTIS
A. TSCS Controls System
B. PSOV Operable or a Blind Flange at Engine/MPT Interface

III. BACKUP RETHREICES
A. FEP-III Phase 2 Test Description
B. FEP-III Final Report 


\section{ACTIVITY}

\section{"EP-2: TRANSFER AND LOADING EXERCISE TO NGTM AND} CHECKOUT OF EMERGENCY DRAIN"

\section{SUMMARY}

This activity covers the initial $\mathrm{LH}_{z}$ transfer exercises to the NGTM and verification of the emergency drain operation.

With the storage and pressurization dewars filled, the pressurization dewar will be self-pressurized and pressurization of the storage dewar via the heat exchanger will be accomplished. When adequate pressure has been established in the storage dewar, $\mathrm{LH}_{2}$ transfer operations to the NGTM will be established. NGTM level and temperature data will be verified and the heat loss characteristics of the NGTM will be verified. Transfer line chillholding data will be obtained relative to future topping exercises. This FEP will be concluded by performing out-flow tests through the NGTM emergency drain system.

II. REQUIREMENTS
1) CP Consoles
6) Fire Protection System
2) $\mathrm{CP} I \& C$
7) $\mathrm{H}_{2}$ Alarm System
3) CP Data System
8) $\mathrm{O}_{z}$ Detectors
4) GHe Bottles
9) Emergency Drain Overboard System
5) Flares \& Burn Pond
10) Hot Water System

III. BACKUP REFERENCES

1) FEP-III Test Description: Liquid Hydrogen System Tests (NTO-I-0136) 
"EP-3: RATED FLOW TESTS OF NGTM AND TOPPING"

I. SUMMARY

This activity covers the NGTM flow and topping tests.

With the NGTM filled, temperature rise-rate tests will be conducted at various ullage pressures and transfer function exercises will be conducted on the pressure/vent system. Flow tests will then be conducted at minimum and maximum rates, with and without topping, through the engine simulator. Fluid samples will be taken during flow testing to establish cleanliness levels and system integrity through the remote connector verified.

II. REQUIREMENTS

1) CP Consoles.

2) $\mathrm{CP} I \& \mathrm{C}$.

3) CP Data System.

4) Engine Simulator (control valve, associated piping and burn-off system).

5) $\mathrm{H}_{2}$ Alarm System.

6) $\mathrm{O}_{2}$ Detectors.

7) Fire Protection System.

8) $\mathrm{GHe}$.

9) Hot Water System.

\section{BACKUP REFERENCES}

1) ETS-1 Activation Specification (NTO-I-0094).

2) FEP-III Test Description: Liquid Hydrogen System Tests (NTO-I-0136) 
ACTIVITY

$\mathrm{LH}_{2}$ STORAGE AIND PRESSURIZATION DEWARS

"GN 2 LEAK TEST"

I. SUMMARY

This activity covers the $\mathrm{GN}_{2}$ leak test of the $\mathrm{LH}_{2}$ storage and pressurization dewars, fill systems and heat exchangers.

The $\mathrm{LH}_{2}$ dewars, fill systems, and heat exchangers will be pressurized to $75 \%$ of the operating pressure and then reduced to their respective leak test pressure settings with $\mathrm{GN}_{2}$. The pressure holding capability of each valve will be demonstrated and a system leak test performed in preparation for the $\mathrm{LN}_{2}$ cryo shock and cold leak-tests. The vacuum jackets associated with these systems will be pumped down to operating pressure and the jackets and pumping system will be checked for operational characteristics and integrity. A blow down of the dewars will be conducted through the fill system to verify system cleanliness.

II. REQUIREMEITS
A. Electrical Power
B. $\mathrm{GN}_{2}$ Trailers
C. Leak Detectors (sonic type)
D. Temporary I\&C Equipment
E. Contaminant Trap or Target 


\section{$\mathrm{LH}_{2}$ STORAGE AIND PRESSURIZATION DEWARS: \\ "INSTALT \& CHECKOUT INSTRUNENTATION"}

I. SUMMARY

This activity covers the installation and checkout of the permanent and temporary transducers on the storage and pressurization dewars.

The permanent and temporary transducers will be installed along with the mounting brackets, rakes etc. Associated wiring will be run and integrated with the temporary I\&C checkout equipment as required. Various resistance and continuity checks will be performed and calibrations made where applicable. Functional checks will be performed on all valves.

II. REQUIREMENTS
A. Electrical Power
B. Scaffolding
C. Temporary I\&C Checkout Equipment
D. Temporary Control System

III. BACKUP REFERENCES

A. ETS-I Activation Specification (NTO-I-0094) 


\section{ACTIVITY}

\section{$\underline{\mathrm{LH}}_{2}$ STORAGE AND PRESSURIZATION DEWARS:}

"LN 2 CRYO SHOCK AND LEAK TEST"

\section{SUMMARY}

This activity covers the initial cryo-shock $\left(\mathrm{LN}_{2}\right)$ of the $\mathrm{LH}_{2}$ storage and Pressurization Dewars and cold leak-test of these systems.

The subject dewars will be chilled and filled to approximately 10\% following pulldown of the vacuum annuli. The pressurization dewar will be pressurized (checking out the self-pressurization system) with $\mathrm{GN}_{2}$ to the pressure required to chilldown the heat exchangers. At this point, the $\mathrm{LH}_{2}$ vaporizer will be functionally checked with $\mathrm{LN}_{2} \cdot \mathrm{All}$ mechanical fittings in the dewars, fill, and heat exchanger systems will be torque checked and the systems drained. While the dewars and associated systems are cold, a $\mathrm{GN}_{2} / \mathrm{He}$ mixture will be introduced and the systems will be leak tested. The systems will then be evacuated and inerted for the subsequent $\mathrm{H}_{2}$ operations.

II. REQUIPEMENTS

1. Electrical Power

2. Vacuum Pumps

3. $\mathrm{IN}_{2}$ Source (tankers or dewar)

4. He Source (trailer or tank farm)

5. $\mathrm{GN}_{2}$ Source (trailers or $\mathrm{LN}_{2}$ vaporizer)

6. He Leak Detectors

7. Temporary I\&C Equipment

III. BACKUP REFERENCES

1. ETS-1 Activation

2. $\mathrm{LN}_{2}$ Loading of $\mathrm{V}-5001$ and Cryogenic Leak Tests (NTO-I-0153) 


\section{ACTIVITY}

IH/ STORAGE AND PRESSURIZATION SYSTMMS: "IH 2 VAPORIZER CHECKOUT WITH LH,"

\section{SUMMARY}

This activity covers the checkout of the $\mathrm{LH}_{2}$ vaporizer pumping characteristics.

Conduct of this activity requires that the pressurization dewar contains $\mathrm{LH}_{2}$ and can be accomplished concurrent with "Initial $\mathrm{IH}_{2} \mathrm{~F} 11 \mathrm{l}$ and Pressurization System Checkout". Following chllldown of the $\mathrm{IH}_{2}$ vaporizer supply system, the pumping operations will be initiated. Pumping rate will be established by comparing initial $\mathrm{GH}_{2}$ storage pressure with final $\mathrm{GH}_{2}$ storage pressure. The system will be checked for leakage and operation of all valves, pressure, and temperature switches will be verified.

II. REQUIREMENTS
A. C.P. Consoles
B. $\mathrm{IH}_{2}$ in Pressurization Dewar
C. Leak Detector
D. Fire Protection System
E. $\mathrm{H}_{2}$ Alarm System

\section{BACKUP REFERENCES}

A. ETS-1 Activation Specification (NTO-I-0094). 


\section{SUMMARY}

This activity covers the installation and checkout of the permanent and temporary transducers on the high pressure $\mathrm{LH}_{2}$ dewars.

The permanent and temporary transducers will be installed along with the mounting brackets, rakes, etc. Associated wiring will be run and integrated with the temporary I\&C checkout equipment as required. Various resistance and continuity checks will be performed and calibrations made where applicable. Functional checks will be performed on all valves.

II. REQUTREMIMITS
A. Electrical Power
B. Scaffolding
C. Temporary I\&C Checkout Equipment
D. Temporary Control System

III. BACKUP REFEREMTCES

A. ETS-1 Activation Specification (NTO-I-0094) 


\section{ACTIVITY}

HIGH PRESSURE IH/2 DEWARS: "GN 2 LEAK TEST"

\section{SUMMARY}

This activity covers the $\mathrm{GN}_{2}$ Leak Check of the High Pressure Dewars.

The $\mathrm{LH}_{2}$ dewars and $\mathrm{flll}$ systems will be pressurlzed to $75 \%$ of the operating pressure and then reduced to their respective leak test pressure settings with $\mathrm{GN}_{2}$. The pressure holding capability of each valve will be demonstrated and a system leak test performed in preparation for the $\mathrm{IN}_{2}$ Cryo Shock and Cold Leak Tests. The vacuum jackets associated with these systems will be pumped down to operating pressure and the jackets and pumping system will be checked for operational characteristics and integrity. A blowdown of the dewars will be conducted through the fill system to verify system cleanliness.

II. REQUIREAETTS
A. Electrical Power
B. $\mathrm{Gr}_{2}$ Trailers
C. Leak Detectors (Sonic type)
D. Temporary I\&C Equipment
B. Contaminant Trap or Target 


\section{ACTIVITY}

BIGH PRESSURE IHz DEWARS: "IN/2 CRYO-SHOCK AIT IEAK TEST"

\section{SURMARY}

This activity covers the initial cryo-shock ( $\left.\mathrm{N}_{2}\right)$ of the high pressure dewars and cold leak test of these systems.

The vacuum annuli of the high pressure dewars and associated systems will be pulled down to operating pressure and the dewars will be chilled and filled to approximately _. \%. The dewars will be pressurized and $\mathrm{IN}_{2}$ transferred to the NGTM interface. All mechanical fittings in the dewars and associated systems will be torquechecked and the systems drained. While the dewars and associated systems are cold, a $\mathrm{Gr}_{2} /$ GHe mixture will be introduced and the systems w1ll be leak tested. The systems will then be evacuated and inerted for the subsequent $\mathrm{H}_{2}$ operations.

\section{REQUIREMENTS}
A. Electrical Power
B. Vacuum Pumps
C. $\mathrm{IN}_{2}$ Source (Tankers or Dewar)
D. He Source (Trailer or Tank Farm)
E. $\mathrm{GN}_{2}$ Source (Trailers or $\mathrm{IN}_{2}$ Vaporizer)
F. $\mathrm{GH}_{2}$ Source (Trailers or $\mathrm{LH}_{2}$ Vaporizer)
G. He Leak Detectors
H. Temporary I\&C Equipment 
III. BACKUP RENGTRECOS

A. DIS-1 Activation

B. IN Ioading of V-500I and Cryogenic Leak Tests (NTO-I-0153) 


\section{ACTIVITY}

GAS STORAGE BOINIES: "PRESSURP \& IEAK TEST"

\section{SUMMARY}

This activity covers functional checkout of the valves and pressure/leak test of the $\mathrm{GH}_{2}$, $\mathrm{GHe}$ and $\mathrm{GN}_{2}$ fill and storage systems .

All valves in the gas fill and storage systems will be operationally checked. Following above, each gas bottle will be pressurized to its respective operating pressure using $\mathrm{GN}_{2}$, plus GHe ( $\left.90 \% \mathrm{GN}_{2} / 10 \% \mathrm{GHe}\right)$. The pressure will then be reduced and the fill and storage systems leak checked. The pressure-holding capability of each valve will be demonstrated during the above operations. A blowdown of all bottles will be conducted (through the fill system) to verify system cleanliness.

II. REQUTREITNTTS

A. Electrical Power

B. $\mathrm{GN}_{2}$ Source (Trailers or $\mathrm{IN}_{2}$ Vaporizer)

C. GHe Trailer

D. He Leak Detectors

E. Temporary I\&C Equipment

F. Contaminant Trap or Target

III. BACKUP REEERENCES

A. ETS-1 Activation Speciication (NTO-I-0015) 


\section{Activity}

Lit Derars: "Insiall \& Chectou't Instrumentation"

I. Summary

This ectivity covers the installation of the pernenent and temporary transducers on the LIr devars; intejration of the transducers rith the Ierporary I. \&: C Chechonit Hqupmeni; and electrical, mechenical and iunctionel chec's to be conducted prior to Gig testing.

Pollowin installation o: the transduces, assoctated oractets and wiring, various resistance and continuity chec'rs will be peromern. Calibrations ing be persomed and all valves will be functionally checied.

II. Requirements
A. Blectrical Porer
B. Scanfolcin's
C. I \&; $C$ celibration equiphent for piossure, temperature and levol transducers.
D. Temporary contirol systen.

III. Baclun Re erences

A. LIS-I Activation Speciacation (ITO-I-00Q4) 


$$
\begin{aligned}
& \text { ACTLITIY }
\end{aligned}
$$

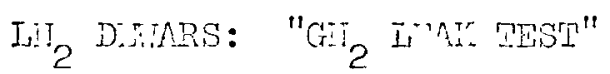

\section{STIETPY}

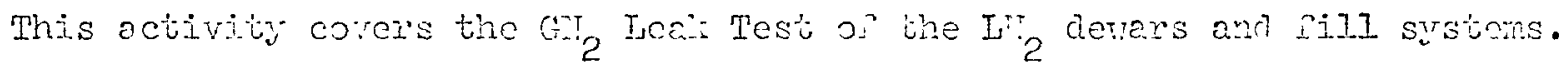

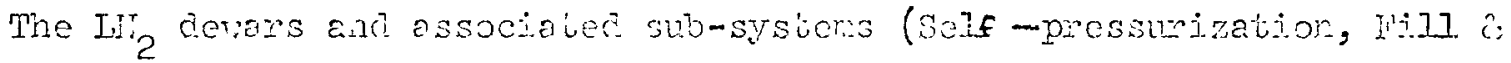

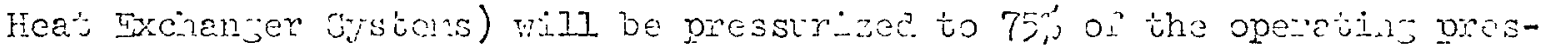
sure and then retuced to their respective leo-iosts prossure sctings rith

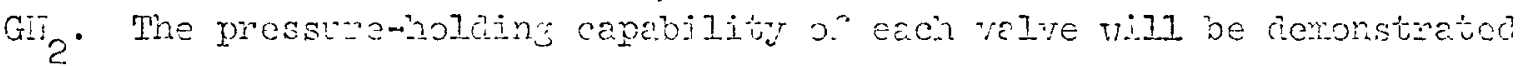

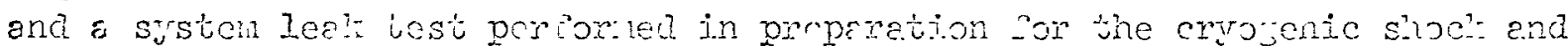

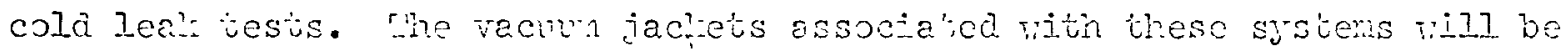

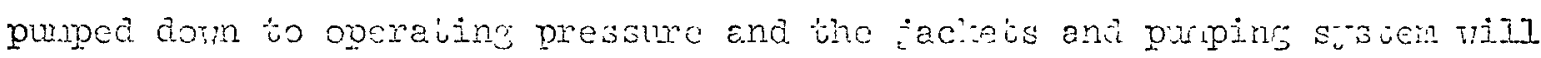

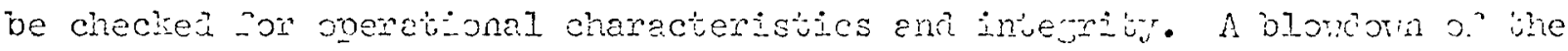

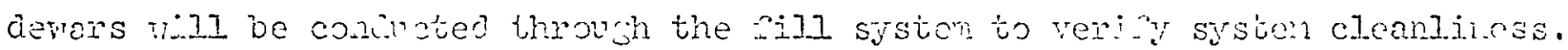

IT. RTRUIREITTES
A. Hectrical poricr
B. Git treilers
C. Lea:- cetectors (sonic-torpo)
D. Terporang I l: C Tquipnont
E. Contaminan' trop or isroet 


\title{
Activity
}

\author{
$\mathrm{IN}_{2}$ Dewars: "IN 2 Cryo. Shock \& Pressure Test"
}

\section{Summary}

This activity covers the initial introduction of $\mathrm{LN}_{2}$ to the $\mathrm{LN}_{2}$ dewars and pressure testing at low temperature.

The $\mathrm{IN}_{2}$ dewars will be chilled and filled (approximately 10\%) and allowed to soak, following pull-down of the vacuum annulus. The primary dewar self-pressurization system will be checkedand the dewar pressurized sufficiently to chilldown the $\mathrm{LN}_{2}$ heat exchanger. All mechanical fittings in the fill, storage and associated systems will be torque checked and the system drained. While the systems are cold, $\mathrm{GN}_{2}$ with a trace of $\mathrm{He}$ will be introduced and the systems leak-checked.

II. Requirements

A. Electrical power

B. Vacuum pump

c. $\quad \mathrm{LN}_{2}$ tanker $(\mathrm{s})$

D. He leak detectors

E. He trailer

F. $\quad \mathrm{GN}_{2}$ trailer

G. Temporary I \& C Equipment

\section{Backup References}

A. ETS-I Activation Specification (NTO-I -0015)

B. $\quad \mathrm{LN}_{2}$ Loading of $\mathrm{V}-5001$ and Cryogenic Leak Tests (NTO-I-0153) Typical 


$$
\begin{gathered}
\text { Activity } \\
\mathrm{IN}_{2} \text { Dewars: "INN } \mathrm{Fill}_{2}
\end{gathered}
$$

\section{Summary}

This activity covers the $\mathrm{IN}_{2}$ fill test of the $\mathrm{IN}_{2}$ dewars. Both dewars will be filled to the 50\% level (approx.) and allowed to soak. Evaporization-loss tests will be conducted to evaluate the insulating characteristics of the vacuum jackets and level/temperature data will be verified insofar as possible. Pressure/vent characteristics of the dewars will be established. The remaining $\mathrm{LNN}_{2}$ will subsequently be used for the $\mathrm{LN}_{2}$ vaporizer checkout. A torque check of all mechanical fittings will be repeated.

II. Requirements

A. Electrical power

B. Vacuum pump

C. $\quad \mathrm{NN}_{2}$ tankers

D. $\mathrm{GN}_{2}$ source (trailers)

E. Gas flowmeters (evaporation-loss test)

F. Temporary I \& C equipment

\section{Backup References}

A. ETS-1 activiation specification (NTO-R-0015)

B. Checkout of $\mathrm{LH}_{2}$ system using $\mathrm{IN}_{2}$ (NTO-I-0020i, typical 


\section{"INSTALIATION OF FACIIITY COOLDOWN STMULATOR"}

\section{SUMMARY}

This activity concerns the installation and checkout of the Facility Cooldown Simulator. The simulator is an arrangement of pipes and valves to simulate engine back pressures at varying flow rates and chamber temperatures. The simulator should be a permanent facility installation to permit checkout of the $\mathrm{IH}_{2}, \mathrm{GH}_{2}, \mathrm{GN}_{2}$, GHe cooldown piping and associated control systems independent of the NGM or shield activities.

II. REQUIREMENTS

See Sketch

III. BACKUP RETEREATCES

A. EIS-1 Flow Simulator 


\section{$\mathrm{LNN}_{2}$ DEWARS: "FEP-I: CHILL \& FILL TO NGTM}

INTERFACE AND FLOW TESTS

I. SUMMARY

This activity covers the initial cooldown flow tests of the $\mathrm{LN}_{2}$ dewar systems to a point upstream of the NGTM umbillical.

Following a functional check of the valves and a $\mathrm{GN}_{2}$ leak check of the cooldown systems, the $\mathrm{LN}_{2}$ dewars will be filled and verification of the level and temperature measuremnts established. Individually, the dewars will be pressurized and the respective cooldown systems chilled and flow tested. Pressure/vent characteristics will be verified. Primary dewar self pressurization system operation will be verified and the $\mathrm{LN}_{2}$ heat exchanger operation will be established. The systems will be flow-tested through the facility cooldown flow simulator at various ullage pressures and control valve settings to simulated engine impedances. Fluid samples will be taken to determine system cleanliness levels. Following the flow tests, the cooldown systems will be drained and charged with a $\mathrm{GN}_{2} / \mathrm{GHe}$ mixture and "cold" leak tests will be conducted. A torque-check of all mechanical fittings in the cooldown systems will be conducted.

II. REQUIREMENTS
A. C. P. Consoles
B. C. P. I\&C
C. C. P. Data System
D. $\quad \mathrm{LN}_{2}$ Tankers
E. He Leak Detectors
F. Facility Cooldown Flow Simulator
G. $\mathrm{GN}_{2}$ Storage System
H. GHe Storage System
I. Flow Measurement Devices 
III. BACKUP REFERENCES

A. ETS-1 Activation Specification (NTO-I-0094)

B. FEP-I Test Description (NTO-I-0129) 


\section{ACTIVITY}

GAS STORAGE BOTTLES: "FEP-II: GASEOUS SYSTEM FLOW TESTS to NGTM INTERFACE"

I. SUMMARY

This activity covers the initial checkout of the $\mathrm{GH}_{\boldsymbol{Z}}$ and $\mathrm{GHe}$ cooldown systems to a point upstream of the NGTM umbilical.

The $\mathrm{GH}_{z}$ and $\mathrm{GHe}$ storage systems will be charged to operating pressure and the cooldown systems will then be individually flow tested through the Facility Cooldown Flow Simulator. Tests will be conducted at various flow rates and back-pressure settings. Control valve responses will be established and preliminary transfer-function data obtained.

II. REQUIREMENTS
A. C.P. Consoles
E. $\quad \mathrm{LH}_{2}$ Vaporizer
B. C.P. I\&C
F. Facility Cooldown Flow Simulator
C. C.P. Data System
G. Oscillator (Control Valve Frequency Response Tests)

III. BACKUP REFERENCES

A. ETS-1 Activation Specification (NTO-I-0094)

B. FEP-II Test Description: Gaseous Cooldown Systems Tests (NTO-I-0131) 


\section{ACTIVITY}

HITGH PRESSURE LHE DEWARS:

"FEP-III: TIITIAL IHE FILL AND FLON TESTS TO NGTM INTERPACE"

I. SUMMARY

This activity covers the initial $\mathrm{IH}_{2} \mathrm{~F} 1 \mathrm{ll}$ and Cooldown Flow Tests to a point upstream of the NGTM Interface.

The vacuum annult will be pulled down to operating pressure and the dewars chilled and filled. A checkout will be conducted of the temperature and level measurement instrumentation. Pressure/vent characteristics will be established and transfer function data will be taken. The cooldown line to the Facility Cooldown Flow Simulator will be chilled and flow tests conducted. Response and transfer function data 111 be taken at various ullage pressures, control valve settings and impedances.

II. REQUIREMIFNIS
A. C.P. Consoles
B. C.P. I\&C
C. C.P. Data System
D. $\mathrm{IH}_{2}$ Tankers
E. $\mathrm{GH}_{2}$ Source
F. GHe Source
G. Osc1llator (Control Valve Frequency Response Tests) 
II. (Continued)

H. Flares (As required)

I. Fire Protection System

J. $\mathrm{H}_{2}$ Alarm System

K. $\mathrm{O}_{2}$ Detectors

L. Facility Cooldown Flow Simulator

III. BACKUP RETIEREATCES

A. EIS-1 Activation Specification (MTO-I-0094)

B. FRP-III Test Description: Iiquid Hydrogen System Tests (NTO-I-0136). 


\section{ACTIVITY \\ FFEP IV}

IH/ STORAGE \& PRWSSURIZAIION DEWARS:

\section{"INITIAL LH2 FILI \& PRESSURIZATION SYSTMM CHECKOUT"}

\section{SUMMARY}

This activity covers the initial fill operations of the $\mathrm{IH}_{2}$ atorage and pressurization dewars and checkout of the heat exchanger and self-pressurization systems.

The subject dewars w11l be chilled and fliled with $\mathrm{LH}_{2}$ and a checkout conducted of dewar temperature and level measurement instrumentation. The pressurization dewar will be checked for pressure/vent characteristics using the self-pressurization system and pressurized to provide flow to the heat exchangers. Heat exchanger operations will be conducted and pressure/vent tests conducted on the storage dewar. Transfer function tests will be conducted on the pressure/vent systems where applicable.

\section{REQUIREMGMIIS}

1. C.P. Consoles

2. C.P. I\&C

3. C.P. Data System

4. $\mathrm{IH}_{2}$ Tankers

5. GHe Source

6. $\mathrm{GH}_{2}$ Storage 
7. Oscillator (Control Valve Frequency Response Tests)

8. Flares (as required) During Venting Operations.

9. Fire Protection System

10. $\mathrm{H}_{2}$ Alarm System

11. $\mathrm{O}_{2}$ Detectors

12. Hot Water System

\section{BACKUP RETRERMCES}

1. EIS-1 Act1 vation Spec1fication (NTO-I-0094).

2. FEP-III Test Description: Ilquid Hydrogen System Tests (NIO-I-0136). 
"FEP-V: COMBINED EMERGENCY COOLDOWN TESTS TO NGTM INTERFACE"

\section{SUMMARY}

This activity covers the integrated flow tests of all the cooldown systems, to a point upstream of the NGTM umbilical.

The vacuum annuli will be pumped down to operating pressure on the high pressure $\mathrm{LH}_{2}$ dewar and the $\mathrm{LN}$ dewars. These dewars and the bottle farm will be filled to capacity. $\mathrm{LH}_{2}$ and $\mathrm{LN}_{2}$ cooldown system chilldown and chill-holding techniques will be verified. Flow Tests of liquid and gaseous systems will be conducted in accordance with the cooldown sequences. Fluid interaction, responses and transfer function data will be obtained.

II. REQUIREMENTS
A. C.P. Consoles
H. $\mathrm{LN}_{2}$ Vaporizer
B. C.P. I\&C
I. Hot Water System
C. C.P. Data System
J. Flares, as required
D. $\mathrm{IN}_{2}$ Tankers
K. Fire Protection System
E. $\mathrm{LH}_{2}$ Tankers
L. $\mathrm{H}_{\mathbf{Z}}$ Alarm System
F. GHe Trailers
M. $\mathrm{O}_{2}$ Detectors
G. $\mathrm{LH}_{2}$ Vaporizer
N. Facility Checkout Device (Control valve, flare and associated piping)

III. BACKUP REFERENCES

A. ETS-I Activation Specification (NTO-I-0094)

B. FEP-IV Test Description: Integrated Cooldown Systems Flow Tests (NTO-I-0171) 


\section{"INSTALL DIGINE FLON SIMUTATOR"}

\section{SURAARY}

This activity covers the installation and checkout of the engine flow simulator.

Following the installation of the IFMM in E/STS-2, the engine flow simulator will be mated to the remote interface. The engine simulator will mate with all fluid systems providing the INE and will permit back-pressure control of the various systems to be tested. All I\&C associated with the engine simulator will be checked out and calibrated. All fluid systems will individually be pressurized to operating pressure with a $\mathrm{GN}_{2} / \mathrm{He}$ mixture and reduce to the leak test setting. Leak tests will be performed to evaluate system integrity and, specifically, remote-connector pressure holding capability. The systems will then be inerted, as applicable, in preparation for flow testing.

II. REQUIRERITNTS
A. Holsting Equipment
B. Temporary Flare System (From the Facility Cooldown Flow Simulator)
C. $\mathrm{CH}_{2}$ Source
D. GHe Source 
II. (Continued)

E. He Leak Detectors

F. Temporary I\&C

III. BACKUP RETEREHCES 


\section{ACTIVIIY}

\section{"PEP-VI: AUXIIIARY SYSTMYS CHECKOYY"}

\section{SUMARY}

This activity covers the checkout of the auxillary engine systems using the Engine Flow Simulator.

The various pneumatic/actuation systens w1.11 be flow-tested to $\mathrm{KE}$ requirements. Pressure, temperature, flow and response-rate data will be taken as required.

\section{REQUIREMTHIS}
A. C.P. Consoles
B. C.P. I\&C
C. C. P. Data System
D. GHe Source
E. $\mathrm{GR}_{2}$ Source
F. $\mathrm{GH}_{2}$ Source
G. $\mathrm{H}_{2}$ Alarm System
H. $\mathrm{O}_{2}$ Detectors
I. F1re Protection System
J. Flare Systems (As required)
R. Engine Simulator

III. BACKUP RHTEREICES 
"FEP-VII: LN $_{2}$ COOLDOWN SYSTEM CHECKOUT WITH ENGINE SIMULATOR"

I. $\quad$ SUMMARY

This activity covers the $\mathrm{LN}_{2}$ cooldown flow verification tests of the low and high pressure systems through the Engine Simulator.

The $\mathrm{LH}_{2}$ Cooldown systems will individually be chilled and flow tested. optimum chilldown and chill-holding techniques will be established and flow system dynamics will be established to simulated engine impedance. Fluid samples will be taken to determine system cleanliness levels. Following the flow tests, the cooldown system will be drained and charged with a $\mathrm{GN}_{2} / \mathrm{GHe}$ mixture and "cold" leak tests will be conducted.

II. REQUIREMENTS
A. C. P. Consoles
B. C. P. I\&C
C. C. P. Data System
D. $\quad \mathrm{LN}_{2}$ Tankers
E. $\mathrm{GN}_{2}$ Storage System
F. GHe Storage System
G. Hot Water System
H. He Leak Detectors
I. Engine Simulator

III. BACKUP REFERENCES
A. ETS-I Activation Specification (NTO-I-0094)
B. FEP-I Test Description (NTO-I-0129) 


\section{ACTIVITY}

\section{GAS STORAGE BOTTLES: "FEP-VIII: GASEOUS COOLDOWN SYSTEMS}

\section{SUMMARY}

This activity covers the $\mathrm{GH}_{2}$ and $\mathrm{GHe}$ cooldown systems flow-verification tests through the Engine simulator.

The Bottle Farm will be charged to capacity and the gaseous cooldown systems will be individually flow tested. Tests will be conducted at various flow rates to the simulated engine impedance. Transfer function and response data will be obtained and fluid samples will be taken to verify system cleanliness levels.

II. REQUIREMENTS
A. C.P. Consoles
E. $\mathrm{GH}_{2}$ Source $\left(\mathrm{LH}_{2}\right.$ Vaporizer)
B. C.P. I\&C
F. He Leak Detectors
C. C.P. Data System
G. Engine Simulator
D. GHe Trailers
H. Oscillator (Control Valve Frequency Response Tests)

III. BACKUP REFERENCE
A. ETS-1 Activation Specification (NTO-I-0094)
B. FEP-II Test Description: Gaseous Cooldown Systems Tests (NTO-I-O13I) 


\section{ACTIVITY}

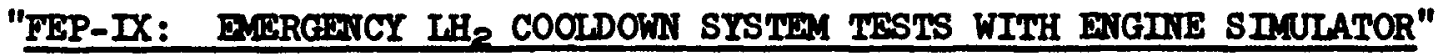

\section{SURMARY}

This activity covers the $\mathrm{IH}_{2}$ cooldown system flow-verification tests through the Engine Simulator.

The $\mathrm{IH}_{2}$ cooldown dewar will be filled and chilldow/chill-holding tests to the cooldown line will be conducted. The Engine simulator will then be chilled and flow tests will be conducted. Response and transfer function data will be taken at various ullage pressures and control valve settings to the simulated engine impedance.

\section{REQUIRFIFIIS}
A. C.P. Consoles
B. C.P. I\&C
C. C.P. Data System
D. GHe Bottles
E. $\mathrm{GH}_{2}$ Bottles
F. GN2 Bottles
G. $\mathrm{H}_{2}$ Alarm System
H. $\mathrm{O}_{2}$ Detectors
I. Fire Protection System 
II. (Continued)
J. Flare Systems (As required)
K. Oscillator (Control Valve Frequency Response Tests)
I. Engine Simulator

III. BACKUP REFEREATCES

A. ETS-1 Activation Specification (NTO-I-0094)

B. FRP-III Test Description: Liquid Hydrogen Systems Tests (NTO-I-0136) 


\section{ACTIVITY}

"FEP-X: COMBINED COOLDOWN SYSTEMS TESTS WITH EMTGINE SIMULATOR"

\section{SUMAARY}

This activity covers the integrated cooldown systems flow-verification tests through the Engine Simulator.

The $\mathrm{IN}_{2}$ and $\mathrm{IH}_{2}$ dewars and bottle farm will be filled to capacity and flor tests will be conducted simulating the engine cooldown sequences. Chill-holding techniques will be verifled and fluid interactions, responses and transfer function data will be obtained.

\section{REQUIREVETITS}
A. C.P. Consoles
B. C.P. I\&C
C. C.P. Data System
D. GHe Bottles
E. $\mathrm{GH}_{2}$ Bottles
F. $\mathrm{GlN}_{2}$ Bottles
G. $\mathrm{IN}_{2}$ Vaporizer
H. $\mathrm{IH}_{2}$ Vaporizer
I. $\mathrm{H}_{2}$ Alarm System
J. $\mathrm{O}_{2}$ Detectors
K. Fire Protection System
L. Flare Systems (As required) 
II. (Continued)

M. Oscillator (Control Valve Frequency Response Tests)

N. Hot Water System

0 . Ingine Simulator

III. BACKUP RINEREATCES

A. ETS-1 Activation Specification (NTO-I-0094)

B. FEP-IV Test Description: Integrated Cooldown Systems Flow Tests (ITO-I-017I) 


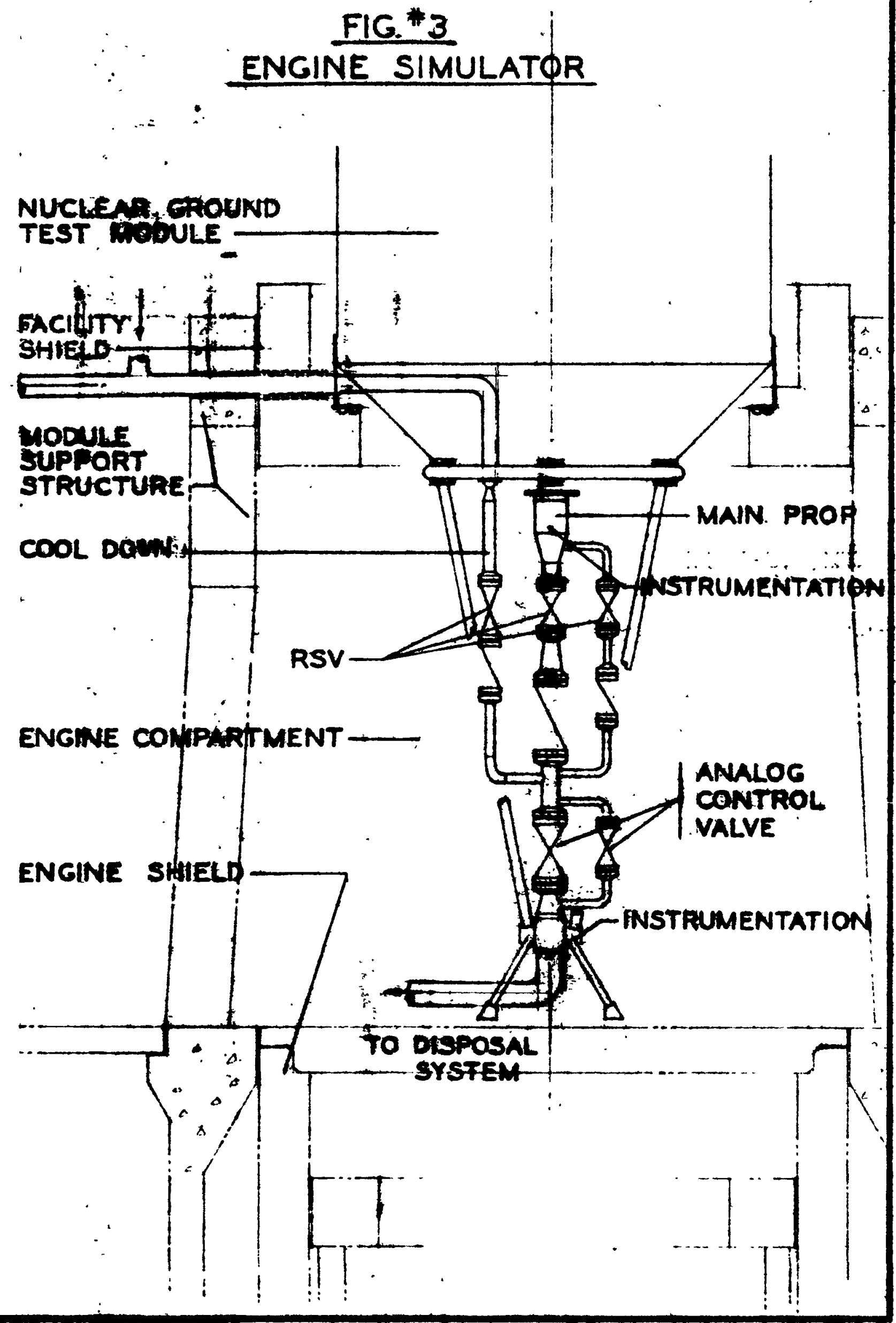




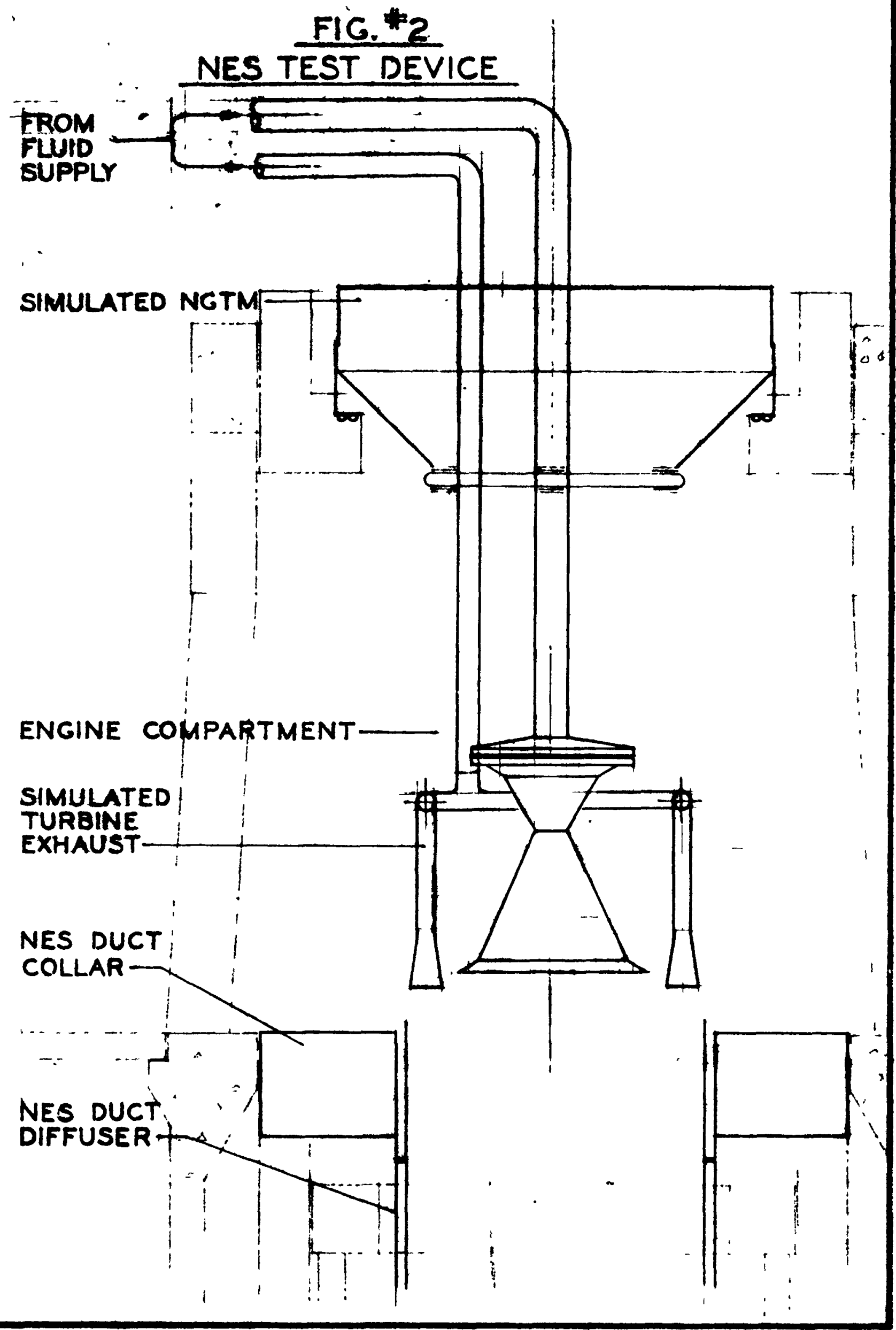




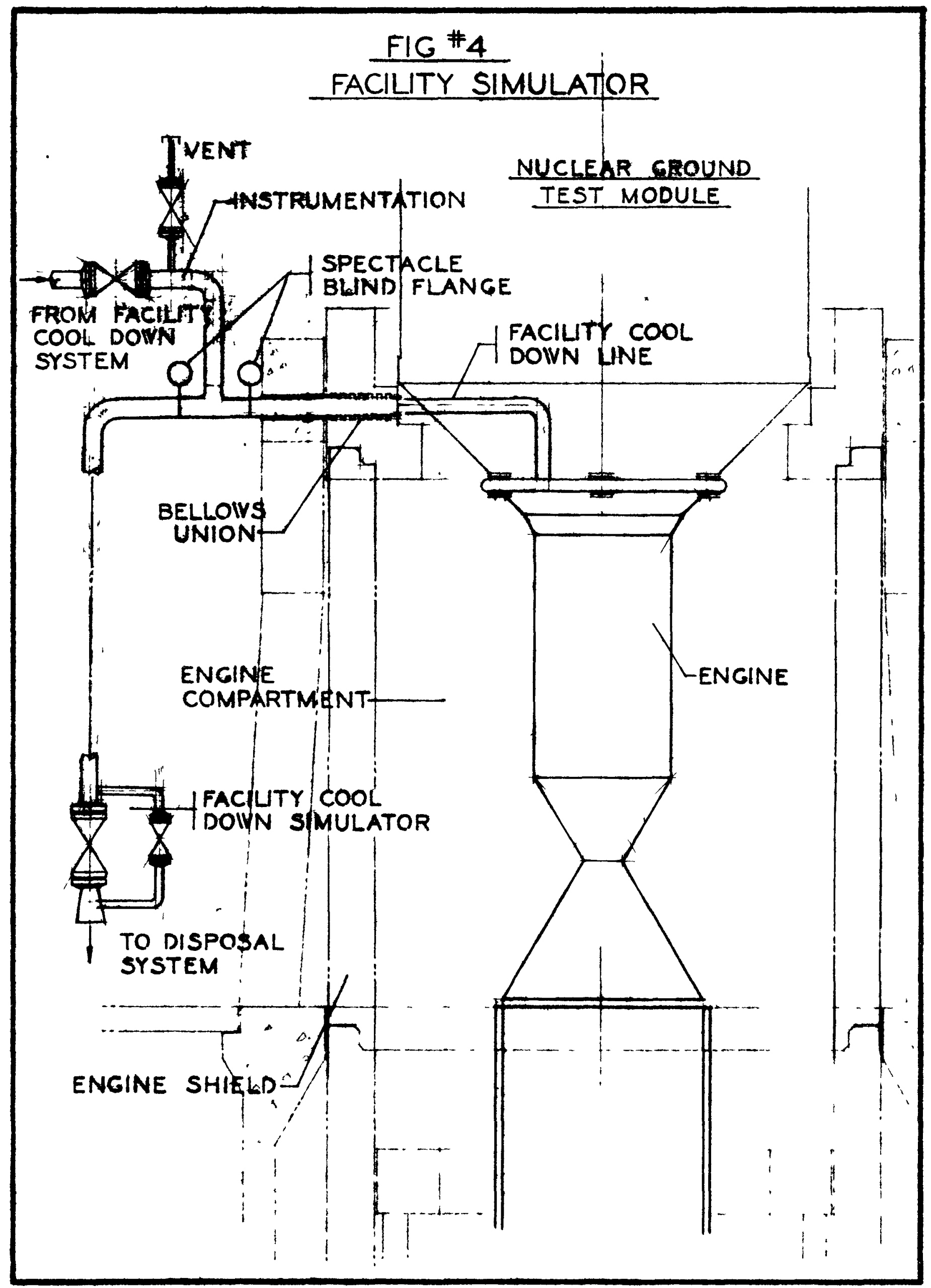




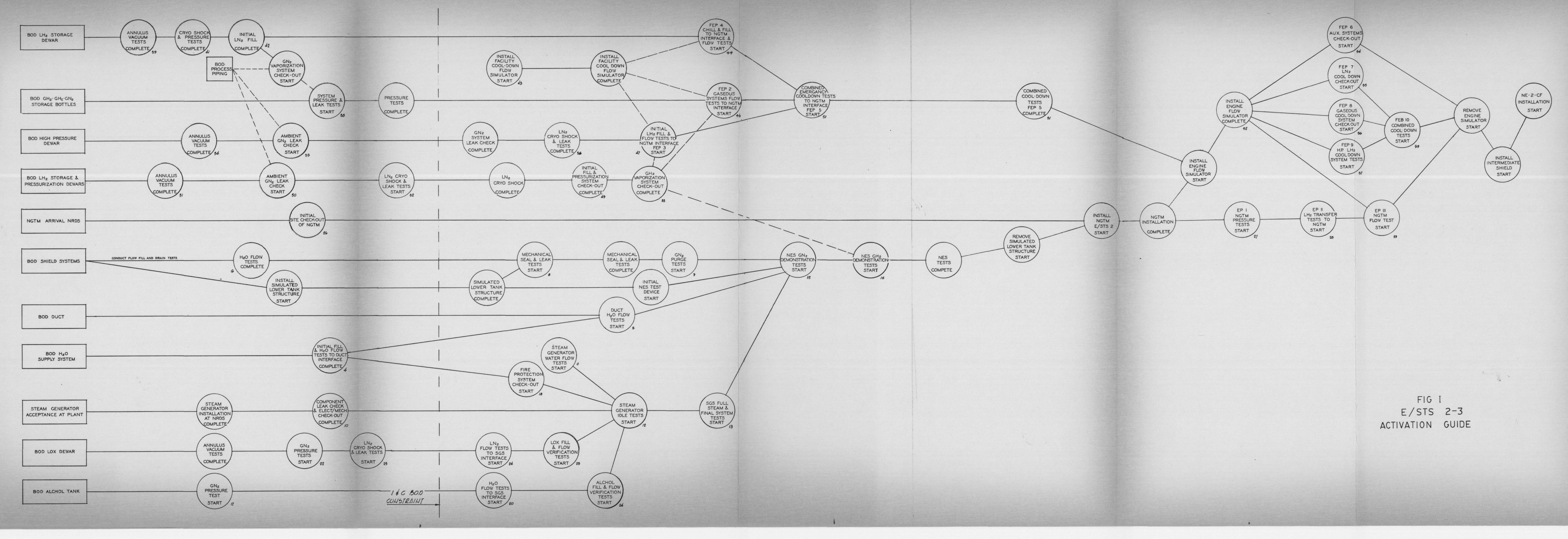

